\title{
Nitrogen Uptake, Efficiency of Use, and Partitioning for Growth in Young Apple Trees
}

\author{
Denise Neilsen ${ }^{1}$ \\ Pacific Agri-Food Research Centre, Summerland, B.C. VOH 1Z0, Canada \\ Peter Millard \\ Macaulay Land Use Research Institute, Craigiebuckler, Aberdeen AB9 2JQ, United Kingdom \\ Gerald H. Neilsen and Eugene J. Hogue \\ Pacific Agri-Food Research Centre, Summerland, B.C. VOH 1Z0, Canada
}

Additional index words. Malus sylvestris var. domestica, remobilization, crop load

\begin{abstract}
Uptake, recycling, and partitioning of $\mathrm{N}$ in relation to $\mathrm{N}$ supply and dry matter partitioning was determined for 3- and 4-year-old 'Elstar' apple trees [(Malus sylvestris (L) Mill. var. domestica (Borkh.) Mansf.] on Malling 9 rootstock in 1994 (year 3) and 1995 (year 4), respectively. Trees received $\mathrm{N}$ yearly as $\mathrm{Ca}\left(\mathrm{NO}_{3}\right)_{2}$ at $20 \mathrm{~g} /$ tree applied on a daily basis through a drip irrigation system. The fertilizer was labelled with ${ }^{15} \mathrm{~N}$ in year 3 to allow quantification of remobilization and uptake. The trees were not allowed to crop in years 1 and 2 and were not thinned in years 3 and 4, thereby establishing a range of crop loads. Dry matter and $N$ contents were measured in fruit, midseason and senescent leaves and prunings collected in year 3 , in midseason leaves, and in components of the whole trees, harvested in fall of year 4 . Labelled $\mathrm{N}$ withdrawn from leaves in year 3 was less than that remobilized into leaves and fruit in year 4, indicating that senescent leaves were not the only source of remobilized $N$. Nitrogen uptake efficiency (total $N$ uptake/ $N$ applied) in year 3 was low $(22.3 \%)$. Of the $N$ taken up, $\approx 50 \%$ was removed at the end of the growing season in fruit and leaves. In fall of year 4, the trees contained about $20 \mathrm{~g} \mathrm{~N}$ of which $50 \%$ was partitioned into leaves and fruit, indicating that the annual $N$ uptake by young dwarf apple trees is low $(\approx 10 \mathrm{~g} /$ tree $)$. Data were pooled to compare dry matter and N partitioning into two major sinks: fruit and shoot leaves. Total fruit dry weight increased, and in year 4, fruit size decreased with fruit number, indicating that growth was carbon (C) limited at high crop loads. The number of shoot leaves initiated in both years was unaffected by fruit number, but leaf size decreased as fruit number increased in year 4 . In year 3 , the amount of both remobilized and root-supplied $\mathrm{N}$ in fruit increased with fruit number, but the $\mathrm{N}$ content of the shoot leaf canopy was unaffected. In general, $\mathrm{N}$ and $\mathrm{C}$ partitioning were coupled and leaf $\mathrm{N}$ concentrations were high $(2.8 \%$ to $3.2 \%)$, suggesting that the low uptake efficiency of fertilizer $\mathrm{N}$ resulted because the availability of $\mathrm{N}$ in the root zone greatly exceeded demand.
\end{abstract}

Adoption of high density planting systems for apple trees (Malus sylvestris var. domestica) in British Columbia and the Pacific Northwest and the use of drip irrigation offer the opportunity to add water to individual trees more precisely than was possible previously. Recent experiments have indicated that when $\mathrm{N}$ is added with water (fertigation) under daily drip irrigation, the concentration of $\mathrm{N}$ in the root zone can be predicted from the concentration of $\mathrm{N}$ in the irrigation water (Neilsen et al., 1998). Moreover, because N concentration in the root zone of coarse-textured soils increases and decreases rapidly with the onset and cessation of fertigation, this system allows temporal control of nutrient availability (Neilsen et al., 1998). In addition, the growth of dwarf apple tree root systems under frequent (e.g., daily), drip irrigation is determined by the size of the wetted zone (Levin et al., 1979) and the roots tend to be shallow (Neilsen et al., 1997b) and clustered around the emitter (Goldberg et al., 1971). Thus, N supply to the root zone can be targeted temporally and spatially in the field with the precision usually associated with potted plant experiments.

It has been reported widely that growth of deciduous fruit trees early in the spring is supported by $\mathrm{N}$ remobilized from storage in woody tissues (Tagliavini et al., 1998; Titus and Kang, 1982;

Received for publication 3 Jan. 2000. Accepted for publication 19 Sept. 2000 Summerland contribution 2055. We thank Linda Herbert for assistance with field plots and A. Midwood for assistance with ${ }^{15} \mathrm{~N}$ analyses. The Washington Tree Fruit Research Commission and the Scottish Office Agriculture, Environment, and Fisheries Department provided funding, which is gratefully acknowledged. The cost of publishing this paper was defrayed in part by the payment of page charges. Under postal regulations, this paper therefore must be hereby marked advertisement solely to indicate this fact

${ }^{1}$ Corresponding author.
Weinbaum et al., 1984) which is in turn related to the previous year's $\mathrm{N}$ supply and is independent of current season $\mathrm{N}$ availability to roots (Millard, 1996). Growth later in the season may be more dependent on root uptake (Tromp and Ovaa, 1976; Weinbaum et al., 1984). The relative contribution of remobilized and root supplied $\mathrm{N}$ may be affected by a number of factors, including soil fertility (Millard, 1996), and timing of fertilizer applications (Weinbaum et al., 1984). In general, fertilizer $\mathrm{N}$ may make a much smaller contribution to leaf growth in mature trees (Sanchez et al., 1992) than in young trees (Millard, 1996), possibly because of a larger storage pool in mature trees and also because of greater competition from a larger fruit sink (Weinbaum et al., 1984, 1987).

Uptake of $\mathrm{N}$ during the growing season occurs in response to tree demand, with uptake rate coupled to carbon $(\mathrm{C})$ supply for the most part (Lemaire and Millard, 1999). Huett (1996) reported that for various horticultural crops a supra optimal $\mathrm{N}$ supply cannot be assimilated. The current research was designed to measure $\mathrm{N}$ use in young apple trees to assist in better matching tree $\mathrm{N}$ supply to demand. The objectives of this study were to use ${ }^{15} \mathrm{~N}$ labelled fertilizer to determine the 1) effect of $\mathrm{N}$ supply on the uptake of fertilizer $\mathrm{N}$ in young apple trees, 2) efficiency of fertilizer $\mathrm{N}$ use by young apple trees under drip irrigation, and 3) relationship between $\mathrm{N}$ and dry matter partitioning.

\section{Materials and Methods}

EXPERIMENTAL DESIGN. 'Elstar' apple trees on Malling 9 (M.9) rootstock planted in May 1992 (year 1) in a drip-irrigated orchard on a Skaha loamy sand soil with low organic matter content 
Table 1. Effect of previous $\mathrm{N}$ treatments on trunk cross-sectional area (TCSA), fruit production, and N uptake of 'Elstar'/M.9 apple trees in years 3 and 4.

\begin{tabular}{|c|c|c|c|c|c|c|c|c|c|}
\hline \multirow{3}{*}{$\begin{array}{l}\mathrm{N} \text { additions } \\
\text { years } \\
1 \text { and } 2 \\
\text { (g/tree) }\end{array}$} & \multicolumn{9}{|c|}{ Fruit } \\
\hline & \multicolumn{2}{|c|}{$\begin{array}{l}\text { TCSA } \\
\left(\mathrm{mm}^{2}\right)\end{array}$} & \multicolumn{2}{|c|}{ No. } & \multicolumn{2}{|c|}{$\begin{array}{l}\text { Size } \\
(\mathrm{g})\end{array}$} & \multicolumn{2}{|c|}{$\begin{array}{c}\text { Yield } \\
\text { (kg/tree) }\end{array}$} & \multirow{2}{*}{$\begin{array}{c}\begin{array}{c}\text { Total N uptake } \\
(\mathrm{mg} / \text { tree })\end{array} \\
\text { Year } 3\end{array}$} \\
\hline & Year $3^{z}$ & Year $4^{y}$ & Year 3 & Year 4 & Year 3 & Year 4 & Year 3 & Year 4 & \\
\hline 5 & 387 & 660 & 10 & 50 & 170 & 158 & 1.7 & 7.9 & 4671 \\
\hline 35 & 542 & 727 & 29 & 42 & 141 & 150 & 4.1 & 6.3 & 4259 \\
\hline SE & 32 & 43 & 5.7 & 30 & 13 & 31 & 0.85 & 1.4 & 430 \\
\hline Significance & $*$ & NS & $*$ & NS & NS & NS & NS & NS & NS \\
\hline
\end{tabular}

Spring sampling.

yFall sampling.

x Sum of labelled N content of fruit, fallen leaves, and prunings in 1993 and that contained in excavated trees in1994.

Ns, ${ }^{*}$ Nonsignificant or significant at $P<0.05$.

(Wittneben, 1986) received $\mathrm{N}$ yearly at the rate of 5 (low $\mathrm{N}$ ) or 35 (high $\mathrm{N}$ ) g/tree as $\mathrm{Ca}\left(\mathrm{NO}_{3}\right)_{2}$ applied daily over a 9-week period starting 17 May in year 1 and 19 May in year 2 (1993). Single tree plots were replicated four times in a randomized complete block design. Fertilizer $\mathrm{N}$ was introduced to the irrigation system through an injector (model 283; Mazzei Injector Corp., Bakersfield, Calif.) and delivered daily in two, 1-h applications through a single $4 \mathrm{~L} \cdot \mathrm{h}^{-1}$ pressure compensating dripper (Hardie Irrigation, El Cajon, Calif.) irrigating at the rate of $8 \mathrm{~L} /$ tree. In year 3 (1994), a new irrigation system was installed in which $\mathrm{N}$ fertilizer and $8 \mathrm{~L}$ water were supplied daily by a 30-min application through two 8 $\mathrm{L} \cdot \mathrm{h}^{-1}$ drippers (Hardie Irrigation) to each tree. Nitrogen was supplied as ${ }^{15} \mathrm{NH}_{4}{ }^{15} \mathrm{NO}_{3}\left(2.1\right.$ atom percent $\left.{ }^{15} \mathrm{~N}\right)$ at the yearly rate of $20 \mathrm{~g}$ /tree over a 10-week period starting 22 Apr. in year 3. Soil solution monitoring of $\mathrm{NO}_{3}-\mathrm{N}$ and $\mathrm{NH}_{4}-\mathrm{N}$ concentrations at $30 \mathrm{~cm}$ depth indicated that $\mathrm{N}$ concentrations remained relatively constant over the period of fertilizer application and that subsequent irrigation flushed fertilizer N out of the root zone (Neilsen et al. 1997a). In year 4 (1995), $\mathrm{Ca}\left(\mathrm{NO}_{3}\right)_{2}$ was applied at the yearly $\mathrm{N}$ rate of $20 \mathrm{~g} /$ tree for an 8-week period starting 2 June. The contribution of $\mathrm{N}$ from soil mineralization was assumed to be low as the soil organic matter content was $<1.2 \%$. Trees were spaced $1.5 \mathrm{~m}$ apart within rows and $4 \mathrm{~m}$ between rows in a slender spindle training system and managed conventionally for insect and weed control (British Columbia Ministry of Agriculture, Fisheries and Food, 1998). Trees were not allowed to crop in years 1 and 2 and in years 3 and 4 were left unthinned. As a result, crop loads ranged from 5 to 57 fruit/tree in year 3 and from 15 to 77 fruit/tree in year 4 .

Plant Measurement and harvest. Trunk diameters were measured in spring year 3 and fall year 4; leaf number per tree was counted on 29 July in year 3 and at tree harvest (11 to 14 Sept.) in year 4; fruit number and weight were determined at harvest (30 Aug. in year 3 and 11 Sept. in year 4). Trees were enclosed with fine, wire meshing in the fall of year 3 and senescent leaves were collected and separated into shoot and spur leaves based on leaf size and shape. Midseason leaf samples were taken in both years after cessation of shoot growth. Samples of five, randomly selected leaves were collected from each tree based on a system in which each branch was numbered and subdivided into quarters so that all parts of the tree had an equal chance of being represented in the sample. Trees were excavated between 11 to 14 Sept. in year 4 . Scions were separated from rootstocks in the field and the roots recovered carefully by hand. Leaves on fruiting spurs were harvested with the fruit and the remaining shoot leaves and nonfruiting spur leaves were collected separately. Branches were subdivided into trunk and first year shoots, second, third, and fourth year shoots. Roots were separated from the rootstock stump and subdivided into coarse $(>1 \mathrm{~mm})$ and fine categories. Nonpeeled fruit segments (core removed) were freeze dried. Leaf samples and fine roots were dried at $65^{\circ} \mathrm{C}$ for 24 h. Woody tissues and coarse roots were dried at $65^{\circ} \mathrm{C}$ until the change in weight between sequential weighings was less than $0.1 \%$. All tissue samples were weighed before and after drying and milled before analysis.

Analysis Of Samples. Total $\mathrm{N}$ and ${ }^{15} \mathrm{~N}$ concentrations in samples were determined using an ANA-SARA mass spectrometer (VG Isogas, Middlewich, Cheshire, United Kingdom). The amounts of fertilizer $\mathrm{N}$ and $\mathrm{N}$ remobilized from plant storage were calculated as described by Millard and Neilsen (1989). In year 3, it was assumed that unlabelled $\mathrm{N}$ was derived from remobilization as the availability and uptake of unlabelled soil $\mathrm{N}$ was expected to be minimal, given the low soil organic matter content at this site.

Statistical analysis. Effects of the year 1 and $2 \mathrm{~N}$ treatments on year 3 and 4 results were determined by analysis of variance using SAS General Linear Model procedures and linear regression analysis using SAS Regression procedures (SAS Inst., Inc., Cary, N.C.).

\section{Results and Discussion}

UPTAKE OF FERTILIZER N. Differential N application rates in years 1 and 2 affected tree trunk cross-sectional area and fruit number in year 3 , but these differences had disappeared by year 4 after trees received the same yearly rate of $\mathrm{N}(20 \mathrm{~g} /$ tree $)$ in years

Table 2. Nitrogen withdrawal from apple leaves during leaf senescence in year 3 (mean of eight trees \pm SE).

\begin{tabular}{|c|c|c|c|c|c|c|}
\hline & \multicolumn{3}{|c|}{ Spur leaves } & \multicolumn{3}{|c|}{ Shoot leaves } \\
\hline & Late June $^{\mathrm{z}}$ & Leaf fall & Withdrawn & Late June ${ }^{\mathrm{z}}$ & Leaf fall & Withdrawn \\
\hline & \multicolumn{6}{|c|}{$\mathrm{N}(\mathrm{mg} /$ tree $)$} \\
\hline Total N & $1567 \pm 270$ & $635 \pm 134$ & $932 \pm 99$ & $3960 \pm 514$ & $3033 \pm 537$ & $927 \pm 365$ \\
\hline Fertilizer ${ }^{15} \mathrm{~N}$ & $249 \pm 48$ & $167 \pm 23$ & $82 \pm 18$ & $1938 \pm 490$ & $1201 \pm 268$ & $737 \pm 208$ \\
\hline Fertilizer ${ }^{15} \mathrm{~N}(\%$ Total $\mathrm{N})$ & $15.9 \%$ & $26.3 \%$ & $8.9 \%$ & $48.9 \%$ & $39.6 \%$ & $79.5 \%$ \\
\hline
\end{tabular}

zValues calculated from data reported by Neilsen et al. (1997a) 
Table 3. Dry weight, total N, and N derived from ${ }^{15} \mathrm{~N}$ enriched fertilizer in components of 'Elstar'/M.9 apple trees during years 3 and year 4 . Labelled fertilizer was applied in year 3 (mean of eight trees $\pm \mathrm{SE}$ ).

\begin{tabular}{|c|c|c|c|c|}
\hline Parameter & $\begin{array}{l}\text { Dry wt } \\
\text { (g/tree) }\end{array}$ & $\begin{array}{l}\text { Total N } \\
(\mathrm{mg} / \text { tree })\end{array}$ & $\begin{array}{c}\text { Labelled N } \\
\text { (mg/tree) }\end{array}$ & $\begin{array}{l}\text { Labelled N } \\
(\% \text { total } N)\end{array}$ \\
\hline \multicolumn{5}{|l|}{ Annual tissue year 3} \\
\hline Fruit & $572 \pm 95$ & $1677 \pm 291$ & $717 \pm 80$ & $42.8 \%$ \\
\hline Fallen leaves & $195 \pm 10$ & $3667 \pm 437$ & $1369 \pm 201$ & $37.3 \%$ \\
\hline Prunings & $66 \pm 7$ & $748 \pm 80$ & $267 \pm 29$ & $35.7 \%$ \\
\hline Total year 3 & $833 \pm 93$ & $6092 \pm 698$ & $2353 \pm 238$ & $38.6 \%$ \\
\hline \multicolumn{5}{|l|}{ Annual tissue year 4} \\
\hline Fruit & $1220 \pm 134$ & $3741 \pm 331$ & $348 \pm 54$ & $9.3 \%$ \\
\hline Leaves & $285 \pm 19$ & $6494 \pm 530$ & $735 \pm 241$ & $11.3 \%$ \\
\hline \multicolumn{5}{|l|}{ Woody tissues year 4} \\
\hline Trunk+year1 shoots & $78 \pm 16$ & $837 \pm 145$ & $75 \pm 8$ & $9.0 \%$ \\
\hline Year 2 shoots & $67 \pm 5$ & $566 \pm 38$ & $74 \pm 12$ & $13.3 \%$ \\
\hline Year 3 shoots & $149 \pm 11$ & $917 \pm 78$ & $103 \pm 4$ & $11.2 \%$ \\
\hline Year 4 shoots & $416 \pm 23$ & $1660 \pm 110$ & $185 \pm 9$ & $11.1 \%$ \\
\hline Stump & $267 \pm 17$ & $1132 \pm 135$ & $136 \pm 9$ & $12.0 \%$ \\
\hline \multicolumn{5}{|l|}{ Roots year 4} \\
\hline Fine & $79 \pm 3$ & $1149 \pm 105$ & $132+17$ & $11.3 \%$ \\
\hline Coarse & $377 \pm 18$ & $3306 \pm 245$ & $324 \pm 42$ & $9.8 \%$ \\
\hline Total year 4 & $3771 \pm 70$ & $19802 \pm 844$ & $2112 \pm 127$ & $10.7 \%$ \\
\hline
\end{tabular}

3 and 4 (Table 1). Although there were significant differences in fruit numbers in year 3 , the previous $\mathrm{N}$ treatments did not affect fruit size or fruit yield significantly. As differences in yields were quite large, the lack of significance was likely, in part, the result of a small sample size. Uptake of fertilizer $\mathrm{N}$ applied in year 3 was measured as the sum of labelled $\mathrm{N}$ removed in fruit, abscised leaves and prunings in year 3 and that retained by the tree in year 4 was also unaffected by differing $\mathrm{N}$ regimes in the previous 2 years (Table 1). Over both treatments, fertilizer uptake averaged $4465 \pm 304 \mathrm{mg}$ which is similar to $\mathrm{N}$ uptake measured for 3-yearold 'Golden Delicious'/M.9 trees grown in the field (Nannipieri et al., 1995) but lower than that measured for similar trees grown in pots (Buwalda and Lenz, 1992; Hansen, 1971).

Nitrogen uptake efficiency ( total $\mathrm{N}$ uptake/amount of $\mathrm{N}$ applied) averaged $22.3 \%$ for the two treatments combined. This figure is lower than $\mathrm{N}$ uptake efficiencies reported for nonbearing 'Agen' prunes (Prunus $\times$ domestica $\mathrm{L}$.) receiving $\mathrm{N}$ during the period of shoot growth (Weinbaum et al., 1978), and alternate bearing 'Kerman' pistachios (Pistacia vera L.) (Weinbaum et al., 1994), but greater than the $1 \%$ to $10 \%$ reported for 'Golden Delicious'/M. 9 trees in the first 5 years after planting (Nannipieri et al., 1995). Inefficient use of $\mathrm{N}$ fertilizer may reflect either inefficient application methods of N, i.e., too short a residence time of added $\mathrm{N}$ in the root zone for interception by the relatively sparse root system typical of apple trees grown in this location (Neilsen et al., 1997b), or a low demand for $\mathrm{N}$ by the trees compared with the amount of $\mathrm{N}$ added. Improving $\mathrm{N}$ use efficiency will require more careful delivery of irrigation water to match plant water requirements and increase the residence time of $\mathrm{N}$ in the root zone as demonstrated for irrigation scheduled in response to measured evaporative demand (Neilsen et al., 1998). In addition, a better knowledge of tree $\mathrm{N}$ requirements is needed. Weinbaum et al. (1992) estimated that over-application of $\mathrm{N}$ to apple orchards in California ranged from 26.2 to $376.4 \mathrm{~kg} \cdot \mathrm{ha}^{-1}$. In the present study, uptake was low compared with recommended rates of $\mathrm{N}$ fertigation in British Columbia which range from 30 to $60 \mathrm{~g} /$ tree for young, dwarf apple trees just coming into production (Okanagan Valley Tree Fruit Authority, 1993).
Uptake of nonfertilizer $\mathrm{N}$ was assumed to be minimal as frequent monitoring indicated that soil solution $\mathrm{N}$ concentrations were low $\left(<5 \mathrm{mg} \cdot \mathrm{L}^{-1}\right)$ outside of the period of fertilizer application (Neilsen et al., 1997a). Moreover, there was no evidence of increased unlabelled (nonfertilizer) $\mathrm{N}$ in the largest $\mathrm{N}$ sinks (shoot and spur leaf canopies) over much of the growing season (Neilsen et al., 1997a).

Nitrogen WithdRAWAL DURING LEAF SENESCENCE. Overall means are presented for leaf $\mathrm{N}$ content as treatments did not vary significantly. The canopy $\mathrm{N}$ content in late June of year 3 estimated previously (Neilsen et al., 1997a) was compared with canopy $\mathrm{N}$ content at abscission in year 3 (Table 2). The $\mathrm{N}$ content per tree in spur leaves was $60 \%$ less than that in shoot leaves both in June and at leaf fall, but about the same amount of $\mathrm{N}$ was withdrawn from both leaf canopies between June and leaf fall $(\approx 930 \mathrm{mg})$. As a result, $59 \%$ of the spur leaf $\mathrm{N}$ content was withdrawn after June compared with $23.4 \%$ of the shoot leaf $\mathrm{N}$ content. It is not possible to determine whether all of the leaf $\mathrm{N}$ withdrawn was retained in the tree into year 4 as some leaf $\mathrm{N}$ was likely translocated into fruit harvested in year 3. In many crops, after shoot growth has ceased, leaves switch from being a strong sink for $\mathrm{N}$ to become a source for reproductive organs (Millard, 1988). It is well-established that spur leaves are a source of carbon assimilates to the fruit they subtend (Forshey and Elving, 1989), and that shoot leaves also contribute later in the growing season (Rom and Ferree, 1986).

The amount of labelled $\mathrm{N}$ contained in spur leaves was also considerably less than in shoot leaves in both late June and at leaf fall in year 3 (Table 2). The amount of labelled $\mathrm{N}$ withdrawn between June and leaf fall was higher for shoot than spur leaves, however, the percentages withdrawn were relatively similar (38\% and 33\%, respectively). The percentage of total $\mathrm{N}$ supplied by fertilizer (labelled $\mathrm{N}$ ) in June, was lower for spur than shoot leaves reflecting the relative importance of remobilized $\mathrm{N}$ for spur leaf growth in the spring and of fertilizer $\mathrm{N}$ for shoot leaf growth later in the season (Neilsen et al., 1997a). For spur leaves, the percentage of total $\mathrm{N}$ supplied by fertilizer was higher at leaf fall $(26 \%)$ than in June (16\%) suggesting a preferential with- 

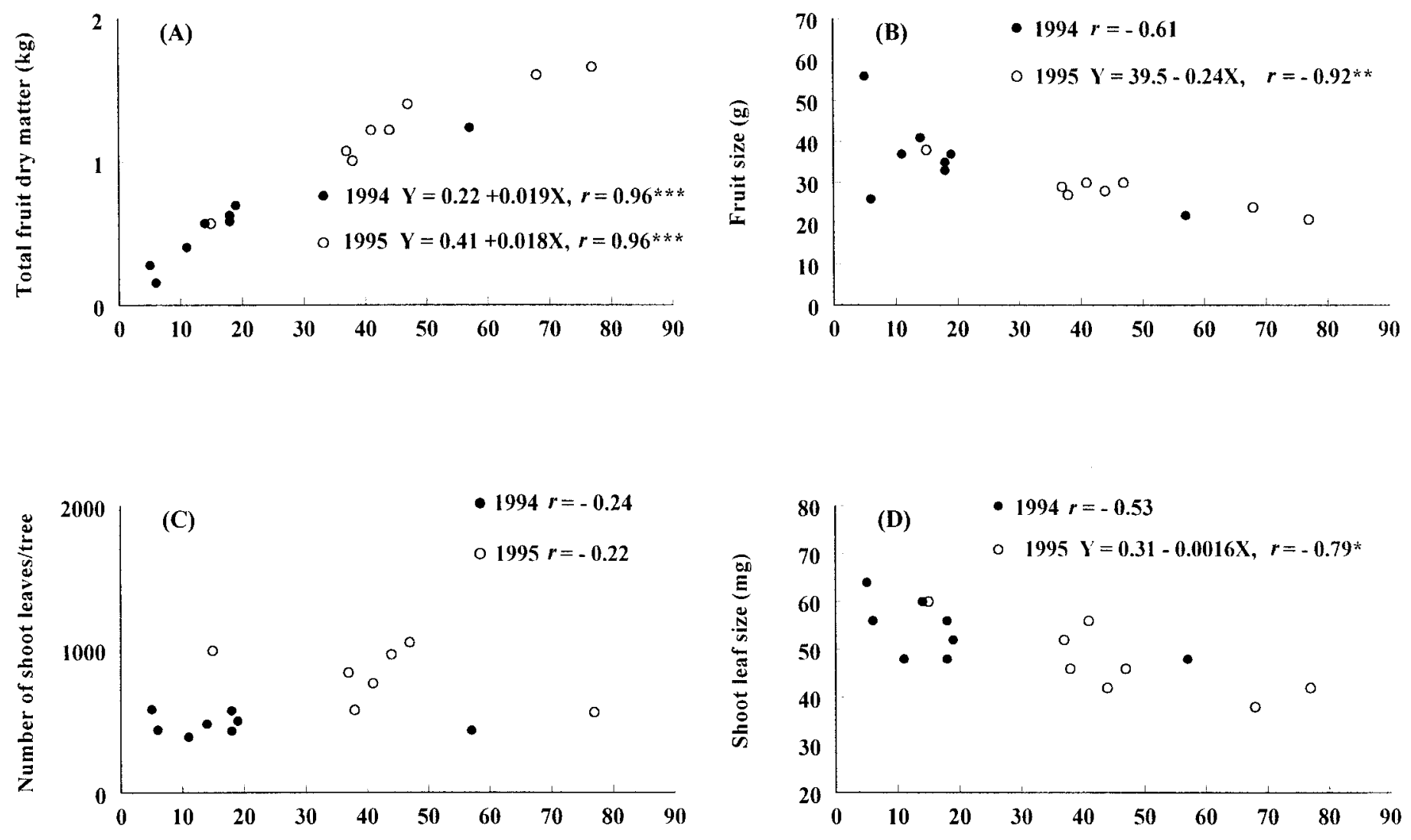

Number of fruit/tree

Fig. 1. Linear regression of fruit number and (A) total fruit dry matter content, (B) fruit size (dry weight), (C) number of shoot leaves, and (D) shoot leaf size of 'Elstar'/ M.9 apple trees in years 3 and 4 . Regression equations are presented when the correlation coefficients $(r)$ were statistically significant at $P<0.05(*), 0.01(* *)$ or $0.001(* * *)$.

drawal of $\mathrm{N}$ derived from storage in the spring, whereas the opposite was true for shoot leaves. For shoot leaves, these findings are similar to those of Sanchez et al. (1992), who showed that a higher proportion of $\mathrm{N}$ derived from the current season's uptake than from remobilization was withdrawn from senescent leaves when the canopy as a whole (spur + shoot leaves) was considered.

Partitioning of dry MatTer and n. Overall means are presented for partitioning of dry weight and $\mathrm{N}$ (Table 3 ) as previous $\mathrm{N}$ treatments did not affect distribution of $\mathrm{N}$ and dry weight in trees in either year 3 or year 4 . The only exception was the amount of labelled $\mathrm{N}$ contained in year 3 shoots, which was higher for trees receiving low $\mathrm{N}$ than for trees receiving high $\mathrm{N}(124 \mathrm{mg}$ and $87 \mathrm{mg}$, respectively).

Dry MatTer accumulation. Fruit and leaves have been classified as 'annual tissue', although it is recognized that there is also annual turnover of root tissue. Similar amounts of dry weight were contained in the framework and roots as in the annual tissue in year 4. This distribution was likely a function of both tree age and the use of a dwarfing rootstock as annual growth formed a much smaller fraction of total growth for 6- and 7-year-old 'Comice'/'Provence' pear (Pyrus communis L.) trees (Sanchez et al., 1992). A similar ratio of annual to permanent tissue was found for 3-year-old fruiting 'Golden Delicious'/M.9 trees (Hansen, 1973).

In year 4, the total dry weight of fruit and leaf tissue was double that in year 3. During this time period, trunk cross-sectional area increased by $50 \%$ on average, indicating that tree growth was not yet restricted by competition for space, in contrast to large, mature trees in which total dry weight may be relatively constant from year to year as found for almond [(Prunus dulcis) (Mill.) D.A. Webb (syn, Prunus amygdalus Batsch)] (Weinbaum et al., 1987).

Nitrogen CONTENT. In year 4 , total $\mathrm{N}$ content of fruit and leaves was double that of year 3 , while leaves contained about twice as much $\mathrm{N}$ as fruit (Table 3). About $53 \%$ of total tree $\mathrm{N}$ was found in annual tissue and the remainder in the woody tissues. A total of $4465 \mathrm{mg}$ of the labelled $\mathrm{N}$ supplied in year 3 was recovered in tissues removed from the trees in year 3 and during the destructive harvest in year 4 (Table 3 ). Of this total, $\approx 47 \%$ (2086 $\mathrm{mg}$ ) was removed in leaves and fruit in year 3 and another $6 \%$ (267 $\mathrm{mg}$ ) in prunings. In year 4 , the trees contained $\approx 2112 \mathrm{mg}$ of labelled $\mathrm{N}$ of which $\approx 51 \%$ (1083 $\mathrm{mg}$ ) was remobilized into leaves and fruit by the end of the growing season with the remainder found in the woody tissue. Using sequential annual dilution of labelled fertilizer $\mathrm{N}$ in mature almond trees, Weinbaum et al. (1987) estimated a 50\% annual removal of $\mathrm{N}$, under the assumption that the total $\mathrm{N}$ content of the tree was relatively constant in large mature trees. Our data indicate that this ratio is similar even in young apple trees; that is, around half of the total tree $\mathrm{N}$ may be committed to annual tissue and that root-supplied $\mathrm{N}$ may be partitioned similarly.

In year 3 , the labelled $\mathrm{N}$ content of annual tissues and prunings 
mostly year 2 and year 3 shoots) comprised $36 \%$ to $43 \%$ of total $\mathrm{N}$. Therefore, during year 3 , remobilized (unlabelled) $\mathrm{N}$ accounted for $63 \%$ and $57 \%$ of the total $\mathrm{N}$ of leaves and fruit, respectively. In year 4 , only $9 \%$ to $11 \%$ of total leaf and fruit $\mathrm{N}$ content could be accounted for by remobilization from uptake in year 3 as represented by labelled $\mathrm{N}$ (Table 3). As there was insufficient labelled or total $\mathrm{N}$ withdrawn from the leaves during senescence (Table 2) to account for that contained in leaves and fruit in year 4 (Table 3 ), labelled $\mathrm{N}$ originating from storage in another part of the tree must have contributed to leaf and fruit growth in year 4. Similar findings have been reported for other deciduous trees (Millard, 1996).

RELATIONSHIPS AMONG DRY MATTER AND N PARTITIONING. It has been well established that dry matter accumulation of vegetative and reproductive tissue in fruit trees is controlled by the size of the fruit sink (Forshey and Elfving, 1989). The potential size of the fruit sink, which is stronger than the vegetative growth sink throughout much of the growing season is determined by crop load (DeJong and Grossman, 1994). Although it has been shown that nonfruiting apple trees take up more $\mathrm{N}$ than cropping trees (Hansen, 1973) less information is available on the partitioning of $\mathrm{N}$ from remobilization or root uptake in response to the different demands imposed by a range of crop loads. In the current experiment, there were few effects of previous $\mathrm{N}$ treatments on growth, dry matter, and $\mathrm{N}$ partitioning and in addition, the
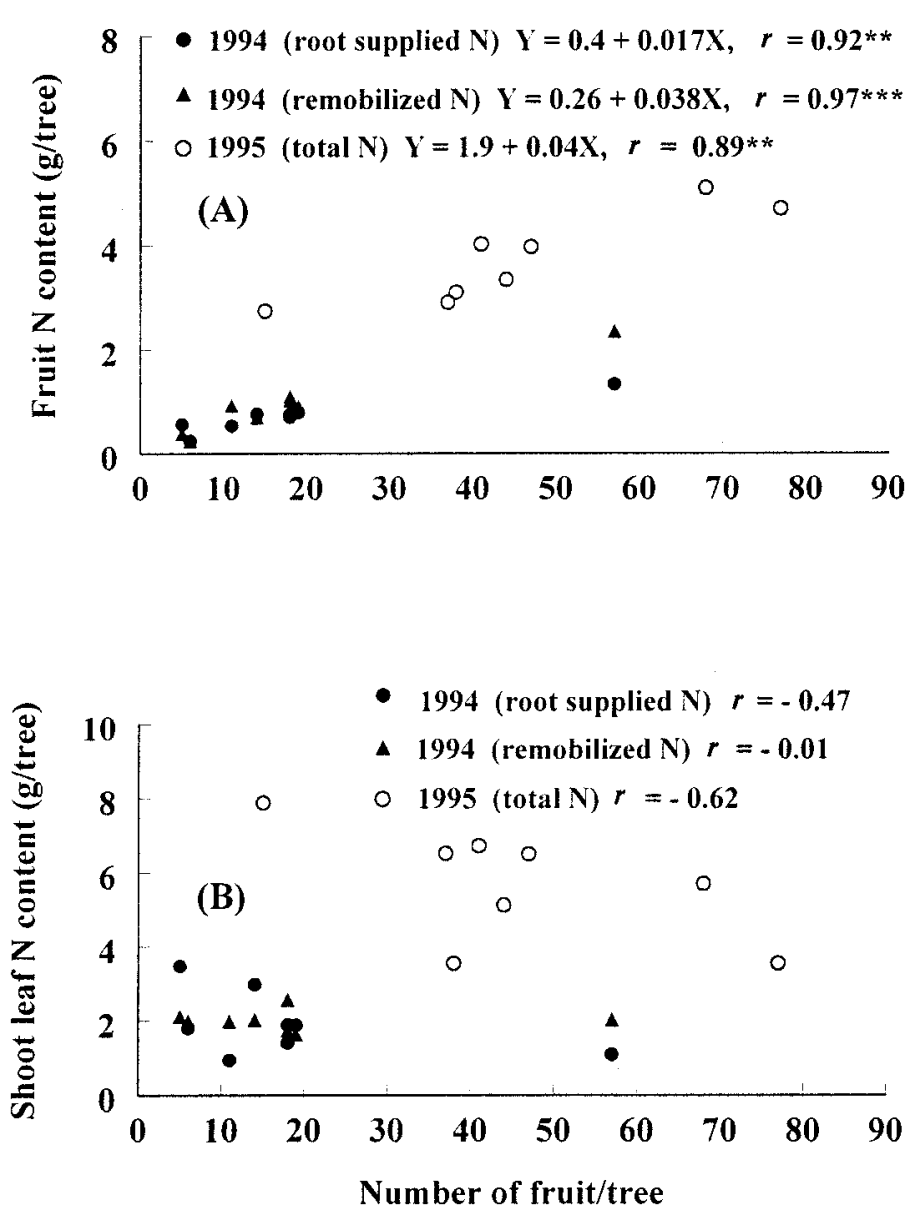

Fig. 2. Linear regression of fruit number and (A) total fruit $\mathrm{N}$ content and (B) shoot leaf canopy N content of 'Elstar'/M.9 apple trees in years 3 and 4. Regression equations are presented when the correlation coefficients $(r)$ were statistically significant at $P<0.01(* *)$ or $0.001(* * *)$. unthinned trees had a range of crop loads. Thus, data were pooled for the two treatments to examine the relationship among crop load, dry matter, and $\mathrm{N}$ partitioning for mature fruit and the shoot leaf canopy in July of both years.

Total growth of both the fruit crop and the shoot leaf canopy consists of two components; number and size of individuals. Total dry matter accumulation of fruit increased with fruit number in both years (Fig. 1A), but not with fruit size (data not presented). The size of individual fruit decreased with fruit number (Fig. 1B) but significantly only in year 4, suggesting that growth of individual fruit at higher crop loads was source-limited as reported previously for peach [Prunus persica (L.) Batsch (Peach Group)] (Grossman and DeJong, 1995). The number of shoot leaves in both years was not related to fruit number (Fig. 1C). However in year 4, when fruit number restricted fruit size, the size of individual shoot leaves decreased as fruit number increased (Fig. 1D). This suggests that canopy development may have been restricted by competition for resources from the total fruit sink and that the mechanism involved was suppression of individual leaf growth rather than the initiation of new leaves.

Both the remobilized (unlabelled) and root supplied (labelled) $\mathrm{N}$ content of the fruit crop in year 3 and the total $\mathrm{N}$ content in year 4 increased with fruit number (Fig. 2A). These findings for $\mathrm{N}$ accumulation in the total fruit sink are analogous to the increase in total fruit dry matter accumulation seen as crop load increases
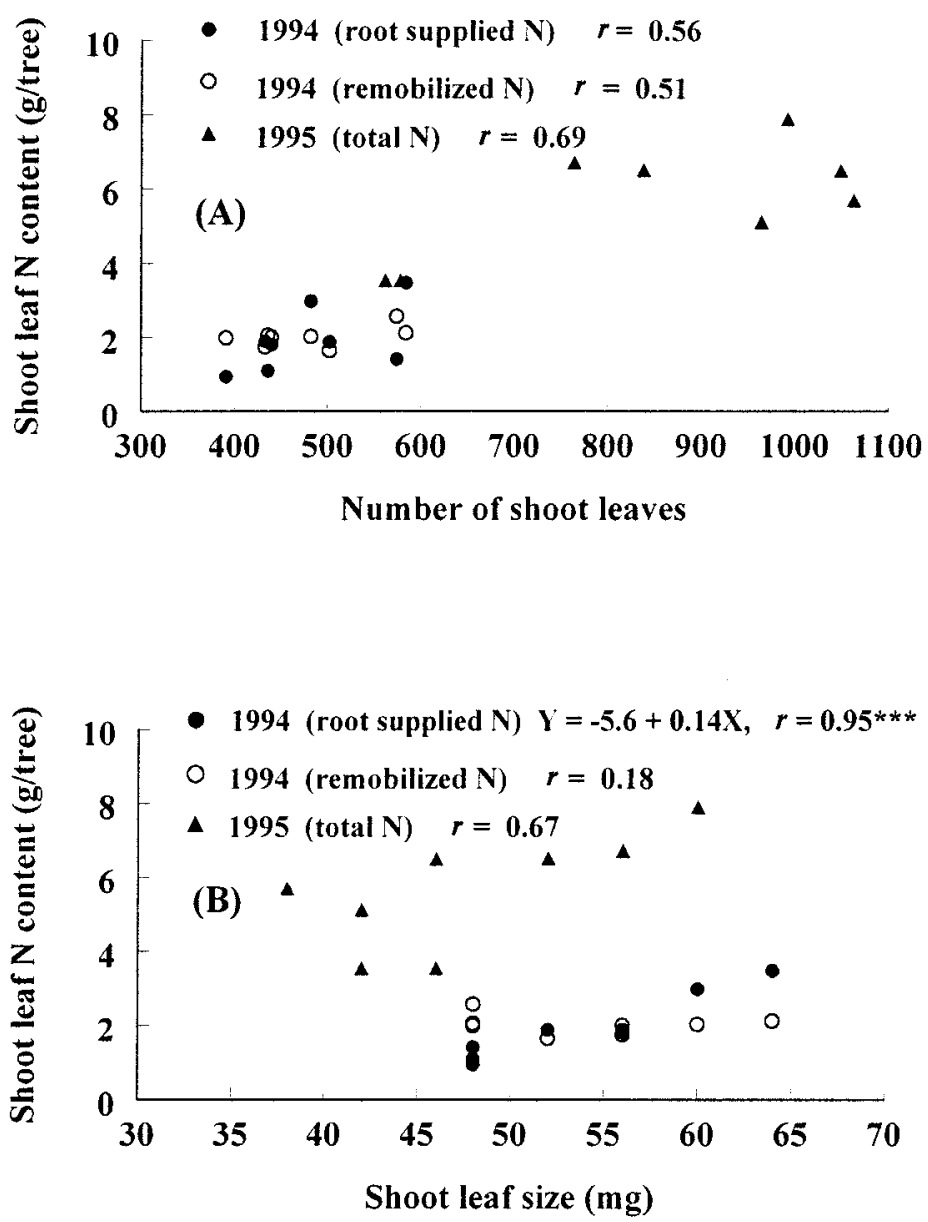

Fig. 3. Linear regression of (A) number of shoot leaves and shoot leaf canopy $N$ content and (B) size of shoot leaves and shoot leaf canopy N content of 'Elstar'/ M.9 apple trees in years 3 and 4 . Regression equations are presented when the correlation coefficients $(r)$ were statistically significant at $P<0.001$ (***). 
(DeJong and Grossman, 1994). Crop load did not affect the amount of $\mathrm{N}$ partitioned into the shoot leaf canopy in either year (Fig. 2B) which parallels the effect of crop load on shoot leaf number (Fig. 1C). Thus, it would appear that crop load effects on $\mathrm{N}$ partitioning to fruit and shoot leaf canopy were closely related to effects on dry matter partitioning. These data indicate that for this set of trees, $\mathrm{N}$ uptake was closely coupled to $\mathrm{C}$ supply and that the plants were likely not limited by $\mathrm{N}$ supply (Lemaire and Millard, 1999). This is borne out by leaf $\mathrm{N}$ concentrations which ranged from $2.8 \%$ to $3.4 \%$ and $2.8 \%$ to $3.1 \%$ in year 3 and year 4 , respectively, which are well above recommended minima for apple leaves (British Columbia Ministry of Agriculture, Fisheries and Food, 1998).

The amount of $\mathrm{N}$ in the shoot leaf canopy was not related to leaf number in either year (Fig. 3A). However, in year 3, the amount of root supplied $\mathrm{N}$ in the shoot leaf canopy increased linearly with the size of individual shoot leaves (Fig. 3B). As the remobilized $\mathrm{N}$ content of the shoot leaf canopy was unrelated to leaf size (Fig. 3B), these findings suggest that individual leaf growth may be determined mainly by root uptake, even though remobilized $\mathrm{N}$ comprised around 50\% of total shoot leaf canopy N in July (Table 2).

The findings discussed above suggest that those components of growth, such as the number of fruit, which are determined in the previous season (floral initiation) and early in the current season (fruit set) (Faust, 1989) are closely related to the amount of $\mathrm{N}$ remobilized into those tissues (Fig. 2A). This raises the possibility that prior to the growing season, the pool of $\mathrm{N}$ available for remobilization into predetermined buds is proportional to the potential size of the sink. In contrast, the number of shoot leaves initiated during the growing season was unrelated to any $\mathrm{N}$ source. However, shoot leaf size was dependent on the current season's N uptake.

\section{Conclusions}

Uptake of $\mathrm{N}$ was unaffected by $\mathrm{N}$ treatments in previous seasons. Current season growth depended on $\mathrm{N}$ remobilized from both previous season leaves and woody tissue as the amount of both total and labelled $\mathrm{N}$ remobilized was greater than that withdrawn from senescent leaves the previous fall. In 4-year-old trees, partitioning of $\mathrm{N}$ to support individual fruit and shoot leaf growth was related directly to dry matter partitioning which was in turn limited by competition for assimilates as crop load increased.

The apparent inefficiency of $\mathrm{N}$ uptake by 3-year-old 'Elstar'/ M.9 apple trees was attributed to excessive $\mathrm{N}$ availability relative to tree demand. Total root $\mathrm{N}$ uptake in 3-year-old 'Elstar'/M.9 apple trees was low $(\approx 5 \mathrm{~g})$ when compared to rates of $\mathrm{N}$ often applied in commercial orchards, and about $50 \%$ of labelled fertilizer $\mathrm{N}$ taken up by the trees was removed in leaves and fruit at the end of that growing season. Similarly, 50\% (10 g) of the total tree N was lost from 4-year-old 'Elstar'/M.9 at the end of the growing season in fruit and fallen leaves. Thus, the yearly amount of $\mathrm{N}$ required to replace that removed from the system the previous year can be estimated from leaf and fruit $\mathrm{N}$ losses for young apple trees as around 5 to $10 \mathrm{~g} /$ tree. Improving the efficiency of $\mathrm{N}$ supply to young apple trees requires a better understanding of the magnitude of tree $\mathrm{N}$ demand, in addition to timely delivery to the roots.

\section{Literature Cited}

British Columbia Ministry of Agriculture, Fisheries and Food. 1998. Tree fruit production guide for interior districts. Ministry of Agriculture, Fisheries and Food. Victoria, British Columbia, Canada.

Buwalda, J.G. and F. Lenz. 1992. Effects of cropping, nutrition and water supply on accumulation and distribution of biomass and nutrients for apple trees on 'M9' root systems. Physiol. Plant. 84:21-28.

DeJong, T.M. and Y.L. Grossman. 1994. A supply and demand approach to modeling annual reproductive and vegetative growth of deciduous fruit trees. HortScience 29:1435-1442.

Faust, M. 1989. Physiology of temperate zone fruit trees. Wiley, New York.

Forshey, C.G. and D.C. Elfving. 1989. The relationship between vegetative growth and fruiting in apple trees. Hort. Rev. 11:229-287.

Goldberg, D., B. Gornat, and Y. Bar. 1971. The distribution of roots, water and minerals as a result of trickle irrigation. J. Amer. Soc. Hort. Sci. 96:645-648.

Grossman, Y.L. and T.M. DeJong. 1995. Maximum fruit growth potential and seasonal patterns of resource dynamics during peach growth. Ann. Bot. 75:553-560.

Hansen, P. 1971. The effects of cropping on uptake, contents and distribution of nutrients in apple trees. Tidskr. Planteavl. 75:615-625.

Hansen, P. 1973. The effect of cropping on the growth and uptake of nutrients by apple trees at different levels of nitrogen, potassium, magnesium and phosphorus. Acta Agr. Scand. 23:86-92.

Huett, D.O. 1996. Prospects for manipulating the vegetative-reproductive balance in horticultural crops through nitrogen nutrition: A review. Austral. J. Agr. Res. 47:47-66.

Lemaire, G. and P. Millard. 1999. An ecophysiological approach to modelling resource fluxes in competing plants. J. Expt. Bot. 50:15-28.

Levin, I., R. Assaf, and B. Bravdo. 1979. Soil moisture and root distribution in an apple orchard irrigated by tricklers. Plant and Soil 52:31-40.

Millard, P. 1988. The accumulation and storage of nitrogen by herbaceous plants. Plant, Cell, Environ. 11:1-8.

Millard, P. 1996. Ecophysiology of the internal cycling of nitrogen for tree growth. J. Plant Nutr. Soil Sci. 159:1-10.

Millard, P. and G.H. Neilsen. 1989. The influence of nitrogen supply on the uptake and remobilization of stored $\mathrm{N}$ for the seasonal growth of apple trees. Ann. Bot. 63:301-309.

Nannipieri, P., C. Ciardi, M. De Nobili, F. Franzin, L. Leita, L. Vittori Antisari, M. Zamborlini, and P. Sequi. 1995. The uptake of ${ }^{15} \mathrm{~N}$ enriched urea by young apple trees in a coarse textured soil. Adv. Hort. Sci. 9:61-66.

Neilsen, D., P. Millard, G.H. Neilsen, and E.J. Hogue. 1997a. Sources of $\mathrm{N}$ for leaf growth in a high density apple (Malus domestica) orchard irrigated with an ammonium nitrate solution. Tree Physiol. 17:733739.

Neilsen, D., P. Parchomchuk, G.H. Neilsen, and E.J. Hogue. 1998. Using soil solution monitoring to determine the effects of irrigation management and fertigation on nitrogen availability in high-density apple orchards. J. Amer. Soc. Hort. Sci. 123:706-713.

Neilsen, G.H., P. Parchomchuk, R. Berard, and D. Neilsen. 1997b. Irrigation frequency and quantity affect root and top growth of fertigated 'McIntosh' apple on M.9, M.26 and M.7 rootstock. Can. J. Plant Sci. 77:133-139.

Okanagan Valley Tree Fruit Authority. 1993. Fertigation guidelines in high density apples and apple nurseries in the Okanagan-Similkameen valleys. Okanagan Valley Tree Fruit Authority, Summerland British Columbia, Canada.

Rom, C.R. and D.C. Ferree. 1986. Influence of fruit on spur leaf photosynthesis and transpiration of 'Golden Delicious' apple. HortScience 21:1026-1029.

Sanchez, E.E., T.L. Righetti, D. Sugar, and P.B. Lombard. 1992. Effects of timing of nitrogen application on nitrogen partitioning between vegetative, reproductive and structural components of mature 'Comice' 
pears. J. Hort. Sci. 67:51-58.

Tagliavini, M., P. Millard, and M. Quartieri. 1998. Storage of foliaradsorbed nitrogen and remobilization for spring growth in young nectarine (Prunus persica var. nectarina) trees. Tree Physiol. 18:203207.

Titus, J.S. and S. Kang. 1982. Nitrogen metabolism, translocation and recycling in apple trees. Hort. Rev. 4:204-246.

Tromp, J. and J.C. Ovaa. 1976. Effect of time of nitrogen application on amino nitrogen composition of roots and xylem sap of apple. Physiol. Plant. 37:29-34.

Weinbaum, S.A., R.S. Johnson, and T.M. DeJong. 1992. Causes and consequences of over fertilization in orchards. HortTechnology 2:112121.

Weinbaum,. S.A., I. Klein, F.E. Broadbent, W.C. Micke, and T.T. Muraoka. 1984. Effects of time of nitrogen application and soil texture on the availability of isotopically labelled fertilizer nitrogen to repro- ductive and vegetative growth of mature almond trees. J. Amer. Soc. Hort. Sci. 109:339-343.

Weinbaum, S.A., I. Klein, and T.T. Muraoka. 1987. Use of nitrogen isotopes and a light-textured soil to assess annual contributions of nitrogen from soil and storage pools in mature almond trees. J. Amer. Soc. Hort. Sci. 112:526-529.

Weinbaum, S.A., M.L. Mervin, and T.T. Muraoka. 1978. Seasonal variation of nitrate uptake efficiency and distribution of absorbed nitrate in non-bearing prune trees. J. Amer. Soc. Hort. Sci. 103:516519.

Weinbaum, S.A., G.A. Picchioni, T.T. Muraoka, L. Ferguson, and P.H. Brown. 1994. Fertilizer nitrogen and boron uptake, storage, and allocation vary during the alternate-bearing cycle of pistachio trees. J. Amer. Soc. Hort. Sci. 119:24-31.

Wittneben, U. 1986. Soils of the Okanagan and Similkameen valleys. Rpt. 52. British Columbia Soil Survey, Ministry of Environment, Victoria, British Columbia, Canada. 